The Sensory Hand 


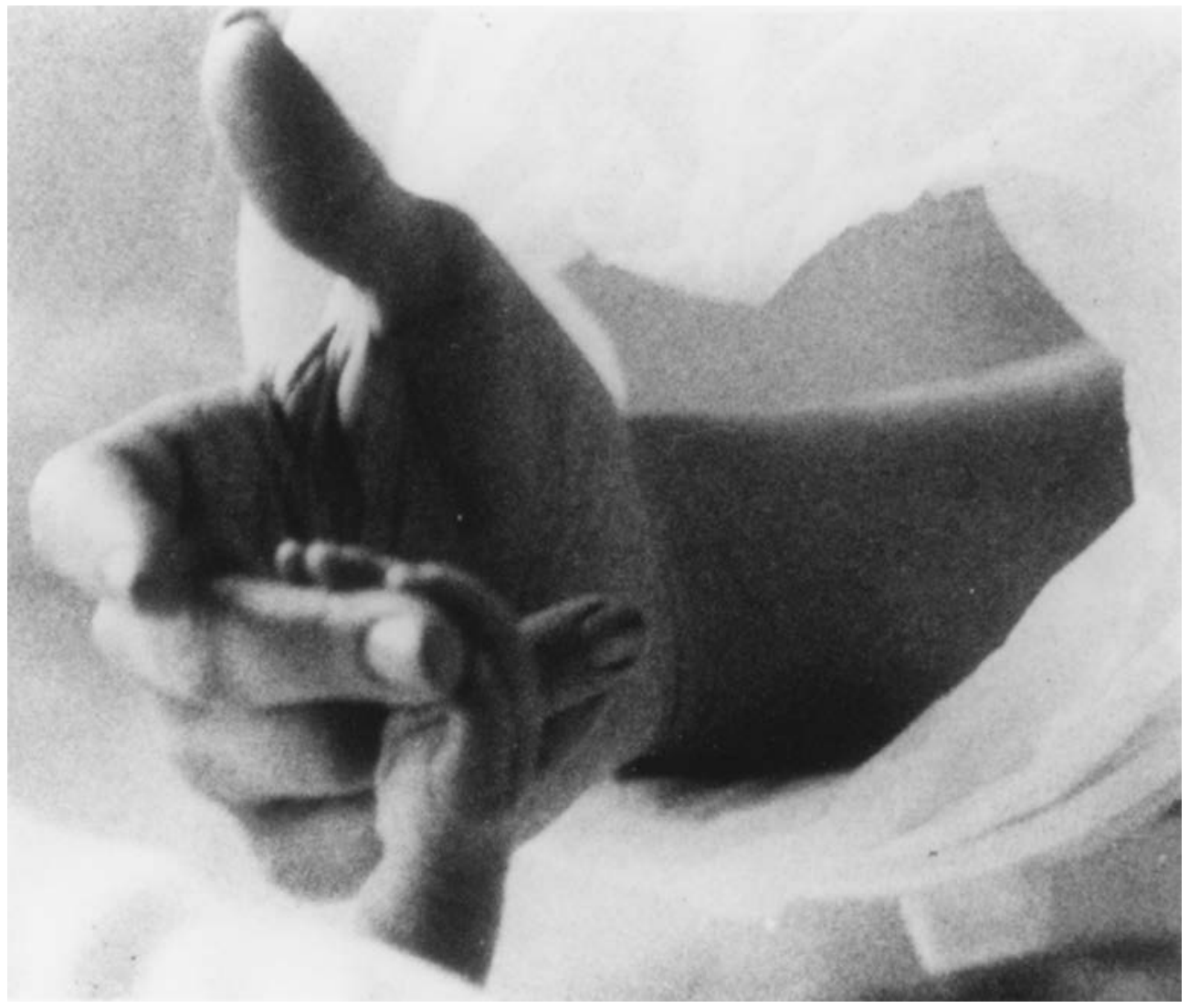

Two parietal lobes in contact. (From Kapinji, 1981.) 


\section{The Sensory Hand}

\section{NEURAL MECHANISMS \\ OF SOMATIC SENSATION}

Vernon B. Mountcastle 
Copyright $\odot 2005$ by the President and Fellows of Harvard College

All rights reserved

Printed in the United States of America

Library of Congress Cataloging-in-Publication Data

Mountcastle, Vernon B.

The sensory hand : neural mechanisms of somatic sensation / Vernon B. Mountcastle.

p. $\mathrm{cm}$.

Includes bibliographical references and index.

ISBN 0-674-01974-1 (alk. paper)

1. Hand-Innervation. 2. Somesthesia. I. Title. QP334.M68 2005

612.97—dc22 2005050372 
Dedicated to the memory of

KENNETH O. JOHNSON, 1938-2005

Distinguished Scientist, Comrade in Research 
